Pacific Journal of Mathematics

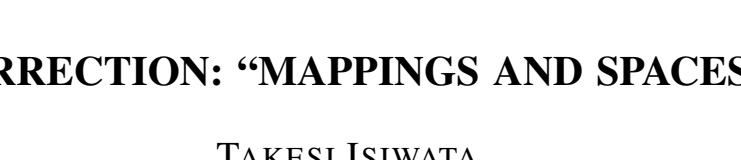




$$
\left\{\frac{n}{2} \frac{\Gamma^{2}\left(\frac{n}{2}\right)}{\Gamma^{2}\left(\frac{n+1}{2}\right)}-1\right\} \sigma^{2}>\frac{\sigma^{2}}{2 n} \frac{4 n+9}{4 n+8}
$$

for $n=1,2, \cdots$.

For $n=2 m,(4)$ may be written as:

$$
\frac{\Gamma^{2}(m+1)}{\Gamma^{2}\left(m+\frac{1}{2}\right)}>m+\frac{1}{4}+\frac{1}{32 m+32}
$$

for $m=1,2, \cdots$.

and for $n=2 m+1$, (4) may be written as:

$$
\frac{\Gamma^{2}(m+1)}{\Gamma^{2}\left(m+\frac{1}{2}\right)}<\frac{\left(m+\frac{1}{2}\right)^{2}}{m+\frac{3}{4}+\frac{1}{32 m+48}}
$$

Thus (5) and (6) taken together prove

$$
\text { for } m=1,2, \cdots \text {. }
$$

$$
\left\{m+\frac{1}{4}+\frac{1}{32 m+32}\right\}^{1 / 2}<\frac{\Gamma(m+1)}{\Gamma\left(m+\frac{1}{2}\right)}<\left\{\frac{\left(m+\frac{1}{2}\right)^{2}}{m+\frac{3}{4}+\frac{1}{32 m+48}}\right\}^{1 / 2},
$$

which also agrees with the result of Boyd [1]. Equation (3) of [2] has to be replaced by equation (7) of this note.

\section{REFERENCES}

1. A. V. Boyd, Note on a paper by Uppuluri, Pacific J. Math. 22 (1967), 9-10.

2. V. R. Rao Uppuluri, On a stronger version of Wallis' formula, Pacific J. Math. 19 (1966), 183-187.

Correction to

\section{MAPPINGS AND SPACES}

TAKesi IsIwata

Volume 20 (1967), 455-480

$(A \Longrightarrow B: A$ should read $B)$

p. 459 line 26 in containing $y_{n} \Longrightarrow$ containing $y_{n}$ in 


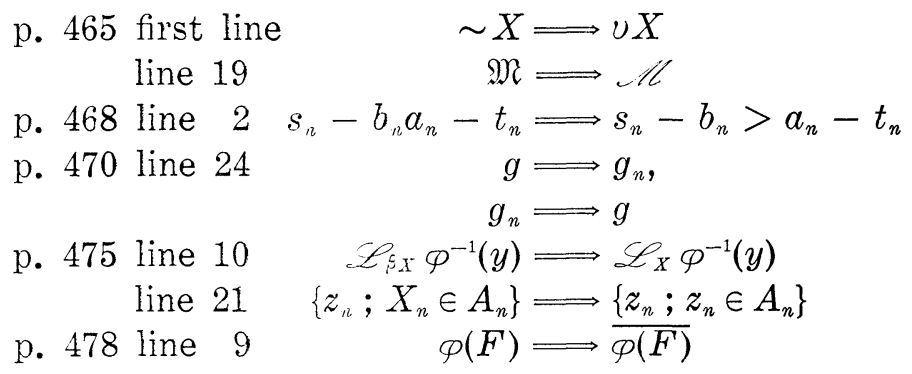

Correction to

PROPERTIES OF DIFFERENTIAL FORMS IN $n$ REAL VARIABLES

H. B. Mann, Josephine Mitchell and Lowell Schoenfeld

Volume 21 (1967), 525-529

Note Added in Proof. In the fifth line of the proof of the Lemma, in place of requiring that $1 \leqq q \leqq p \leqq k$, we should have stipulated that $1 \leqq q \leqq p$ and $q \leqq k$. In the statement of Theorem 1 , the parenthetical remark should be deleted. Finally, in the fourth line of the proof of this theorem, a better reference is Corollary 4.1.2 on p. 101 of Hörmander.

The university affiliations of the three authors are as follows:

Mann-University of Wisconsin and

The Mathematics Research Center,

Mitchell-The Pennsylvania State University.

Schoenfeld-The Pennsylvania State University.

Correction to

\title{
AN INTEGRAL INEQUALITY WITH APPLICATIONS TO THE DIRICHLET PROBLEM
}

\author{
JAMES CALVERT
}

Volume 22 (1967), 19-29

Theorem 1.1 is incorrect as stated. It is correct if the functions $a_{i k}, f_{i}(i=1, \cdots, n)$ are real or the function $u$ is real. I am indebted to Professor R. K. Juberg for pointing this out. 


\section{PACIFIC JOURNAL OF MATHEMATICS}

\section{H. ROYDEN}

Stanford University

Stanford, California

\author{
J. P. JANS \\ University of Washington \\ Seattle, Washington 98105
}

\section{EDITORS}

\author{
J. DugundJI \\ Department of Mathematics \\ Rice University \\ Houston, Texas 77001 \\ Richard ARENS \\ University of California \\ Los Angeles, California 90024
}

\section{ASSOCIATE EDITORS}
E. F. BECKENBACH
B. H. NeumanN
F. WOLF
K. YOSIDA

\section{SUPPORTING INSTITUTIONS}

\author{
UNIVERSITY OF BRITISH COLUMBIA \\ CALIFORNIA INSTITUTE OF TECHNOLOGY \\ UNIVERSITY OF CALIFORNIA \\ MONTANA STATE UNIVERSITY \\ UNIVERSITY OF NEVADA \\ NEW MEXICO STATE UNIVERSITY \\ OREGON STATE UNIVERSITY \\ UNIVERSITY OF OREGON \\ OSAKA UNIVERSITY \\ UNIVERSITY OF SOUTHERN CALIFORNIA
}

\author{
STANFORD UNIVERSITY \\ UNIVERSITY OF TOKYO \\ UNIVERSITY OF UTAH \\ WASHINGTON STATE UNIVERSITY \\ UNIVERSITY OF WASHINGTON \\ AMERICAN MATHEMATICAL SOCIETY \\ CHEVRON RESEARCH CORPORATION \\ TRW SYSTEMS \\ NAVAL ORDNANCE TEST STATION
}

Mathematical papers intended for publication in the Pacific Journal of Mathematics should be typewritten (double spaced). The first paragraph or two must be capable of being used separately as a synopsis of the entire paper. It should not contain references to the bibliography. Manuscripts may be sent to any one of the four editors. All other communications to the editors should be addressed to the managing editor, Richard Arens at the University of California, Los Angeles, California 90024.

50 reprints per author of each article are furnished free of charge; additional copies may be obtained at cost in multiples of 50 .

The Pacific Journal of Mathematics is published monthly. Effective with Volume 16 the price per volume (3 numbers) is $\$ 8.00$; single issues, $\$ 3.00$. Special price for current issues to individual faculty members of supporting institutions and to individual members of the American Mathematical Society: $\$ 4.00$ per volume; single issues $\$ 1.50$. Back numbers are available.

Subscriptions, orders for back numbers, and changes of address should be sent to Pacific Journal of Mathematics, 103 Highland Boulevard, Berkeley 8, California.

Printed at Kokusai Bunken Insatsusha (International Academic Printing Co., Ltd.), 7-17, Fujimi 2-chome, Chiyoda-ku, Tokyo, Japan.

PUBLISHED BY PACIFIC JOURNAL OF MATHEMATICS, A NON-PROFIT CORPORATION

The Supporting Institutions listed above contribute to the cost of publication of this Journal, but they are not owners or publishers and have no responsibility for its content or policies. 


\section{Pacific Journal of Mathematics}

A. A. Aucoin, Diophantine systems ............................. 419

Charles Ballantine, Products of positive definite matrices. I ............... 427

David Wilmot Barnette, A necessary condition for d-polyhedrality ............ 435

James Clark Beidleman and Tae Kun Seo, Generalized Frattini subgroups of finite groups ......................................... 441

Carlos Jorge Do Rego Borges, A study of multivalued functions ............. 451

William Edwin Clark, Algebras of global dimension one with a finite ideal

lattice ...............................................

Richard Brian Darst, On a theorem of Nikodym with applications to weak convergence and von Neumann algebras .........................

George Wesley Day, Superatomic Boolean algebras .....................

Lawrence Fearnley, Characterization of the continuous images of all

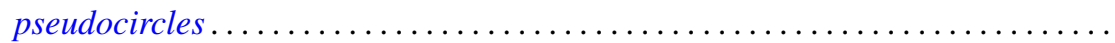

Neil Robert Gray, Unstable points in the hyperspace of connected subsets....... 515

Franklin Haimo, Polynomials in central endomorphisms .................. 521

John Sollion Hsia, Integral equivalence of vectors over local modular lattices . . . . 527

Jim Humphreys, Existence of Levi factors in certain algebraic groups .......... 543

E. Christopher Lance, Automorphisms of postliminal $C^{*}$-algebras ............ 547

Sibe Mardesic, Images of ordered compacta are locally peripherally metric . . . . 557

Albert W. Marshall, David William Walkup and Roger Jean-Baptiste Robert Wets,

Order-preserving functions: Applications to majorization and order

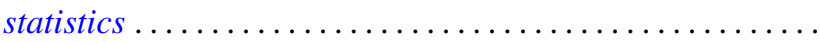

Wellington Ham Ow, An extremal length criterion for the parabolicity of

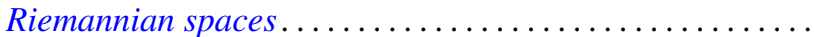

585

Wellington Ham Ow, Criteria for zero capacity of ideal boundary components of

Riemannian spaces...................................... 591

J. H. Reed, Inverse limits of indecomposable continua .................. 597

Joseph Gail Stampfli, Minimal range theorems for operators with thin spectra . . . 601

Roy Westwick, Transformations on tensor spaces..................... 613

Howard Henry Wicke, The regular open continuous images of complete metric

spaces ........................................... 621

Abraham Zaks, A note on semi-primary hereditary rings .............. 627

Thomas William Hungerford, Correction to: "A description of $\operatorname{Mult}_{i}\left(A^{1}, \cdots, A^{n}\right)$

by generators and relations" ............................. 629

Uppuluri V. Ramamohana Rao, Correction to: "On a stronger version of Wallis' formula".............................................. 629

Takesi Isiwata, Correction: "Mappings and spaces" ................... 630

Henry B. Mann, Josephine Mitchell and Lowell Schoenfeld, Correction to:

"Properties of differential forms in $n$ real variables" .... . .

James Calvert, Correction to: "An integral inequality with applications to the

Dirichlet problem"............................. 